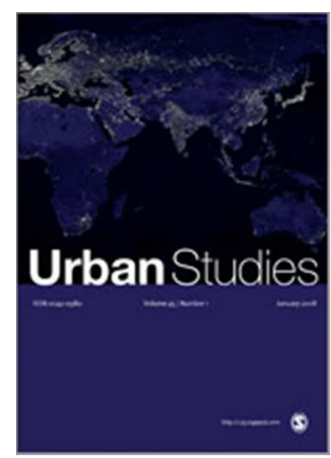

\title{
Brownfield residential development: what happens to the most deprived neighbourhoods in England?
}

\begin{tabular}{|c|c|}
\hline Journal: & Urban Studies \\
\hline Manuscript ID: & CUS-286-11-05.R1 \\
\hline Manuscript Type: & Article \\
\hline $\begin{array}{r}<b>\text { Discipline: Please select a } \\
\text { keyword from the following list } \\
\text { that best describes the } \\
\text { discipline used in your paper.: }\end{array}$ & Planning \\
\hline $\begin{array}{l}\text { World Region: Please select } \\
\text { the region(s) that best reflect } \\
\text { the focus of your paper. } \\
\text { Names of individual countries, } \\
\text { cities \& economic groupings } \\
\text { should appear in the title } \\
\text { where appropriate.: }\end{array}$ & Europe, Western Europe \\
\hline $\begin{array}{l}\text { Major Topic: Please identify up } \\
\text { to two topics that best identify } \\
\text { the subject of your article.: }\end{array}$ & Built environment, Neighbourhood \\
\hline $\begin{array}{r}\text { "Other": If you selected } \\
<\mathrm{i}>\text { 'Other' }</ \mathrm{i}>\text { for } \\
<\mathrm{i}>\text { Discipline }</ \mathrm{i}>\text { or }<\mathrm{i}>\text { Major } \\
\text { Topic }</ \mathrm{i}>\text {, please specify in } \\
\text { the fields provided here.: }\end{array}$ & \\
\hline
\end{tabular}

\section{SCHOLARONE $^{\text {m }}$ \\ Manuscripts}




\title{
Brownfield residential development: what happens to
}

\section{the most deprived neighbourhoods in England?}

\begin{abstract}
Context of Study
Dereliction and vacancy have been an intrinsic part of inner city problems in
\end{abstract} the UK since the early 1970s following the legacy of rapid deindustrialisation. The problems had further escalated in many deprived northern industrial cities throughout the 1980s, which was epitomised by the image of Mrs Thatcher's famous 'walk in the wilderness' on the devastated landscape on the banks of the Tees in 1987 (Harrison, 2010). Besides industrial dereliction, low housing demand in many deprived neighbourhoods also led to high vacancy rates and deterioration of housing stock. Physical regeneration instruments tend to be adopted to deal with these problems. This can be traced back to the targeted slum clearance programmes in the 1950s (Yelling, 2000) through to the use of derelict land grant in the 1980s (Greenhalgh and McCafferty, 1996), and the more recent housing market renewal pathfinders programme (Cameron, 2006). However, it was not until the late 1990s that the policy of regenerating vacant and derelict land became part of a more comprehensive brownfield development strategy.

The Conservative government announced plans to see $50 \%$ of new housing to be built on reused sites in 1995. The new Labour Government announced a more ambitious target in 1998 that at least $60 \%$ of all new built housing in England would be on brownfield land by 2008 (Adams, 2004). This target was subsequently achieved eight years ahead of schedule. Since then the 
share of new housing built on brownfield land has been consistently rising, reaching a provisional estimate of $80 \%$ in 2008 and remaining unchanged in 2009 (CLG, 2010a). The new Coalition government made major changes to brownfield development policy in 2010. Gardens were excluded from the brownfield definition to avoid the side-effects of 'garden grabbing' for housing developments (CLG, 2010b) and all existing regional housing and brownfield targets were abolished. The new policy approach is to make local planning authorities responsible for establishing the level and location of housing provision for the local area. It remains to be seen to what extent this will lead to a major change in the level of brownfield reuse.

Brownfield land in England is officially known as previously-developed land (PDL) as defined in Planning Policy Statement 3 (PPS3): Housing (CLG, 2006) as land 'which is or was occupied by a permanent structure, including the curtilage of the developed land and any associated fixed surface infrastructure'. This comprehensive definition covers different types of land ranging from desirable public green space (e.g. playing fields and gardens) to former housing sites and vacant and derelict land (which includes contaminated industrial sites). However, a narrower definition tends to be adopted in the international arena. For example, the US Environmental Protection Agency ${ }^{1}$ defines brownfield sites as 'real property, the expansion, redevelopment, or reuse of which may be complicated by the presence or potential presence of a hazardous substance, pollutant, or contaminant'. A pan-European survey in 2005 showed that some European countries follow the US definition of real and perceived contamination. The broader definition of PDL tends to be found in Western 
Europe, including Austria, Belgium, France, Germany, the Netherlands and the UK. These countries all have a heavy industrial legacy and high population densities and thus an interest in reusing land instead of developing greenfield sites (Oliver et al. 2005).

The emphasis on brownfield regeneration is not just about regenerating individual sites and their immediate neighbourhood, but also the wider policy context of adopting a more sustainable approach to curb urban sprawl and to reduce the loss of agriculture and rural land (e.g. Dixon, 2006; Dull and Wernstedt, 2010; Longo and Campbell, 2007; National Round Table on Environment and the Economy, 2003; Spaans et al., 2011). There has been a long tradition of using urban containment policy in England since the postwar years. The green belt is the key instrument to define the boundary of urban growth and to restrict overspill development into rural areas (Hall, 1974). Similar but less restrictive measures are also found across Europe to restrict greenfield development (Uhel, 2006). The recent strategic reuse of brownfield land is a policy instrument deployed in the UK to achieve multiple objectives (DETR, 2000a; English Partnership, 2003). On the one hand it is an extension of established urban containment policies aiming at curbing urban sprawl and greenfield development and concentrating housing development on brownfield sites with increased density requirements (Urban Task Force, 1999). On the other hand, it is positively used to contribute to the delivery of the sustainable communities agenda (ODPM, 2003) by regenerating deprived urban areas. The notion of bringing people back to towns and cities by removing environmental degradation (HM Government, 2005) and exploiting the untapped 'urban 
capacity' (Barker, 2003; English Partnerships, 2003) has been politically appealing.

In spite of the rhetoric of embracing sustainable development and community capacity-building in brownfield regeneration strategies over the last decade (Raco and Henderson, 2006), little is known about the actual economic and community impacts, intended and unintended, brought by brownfield development to deprived neighbourhoods. Previous studies, mostly relying on qualitative data and local authority case studies, tend to focus on examining the barriers and drivers of brownfield regeneration (e.g. Greenberg et al., 2001 and Wernstedt et al., 2006 for the US and Adams and Watkins, 2009; Dixon et al., 2006 and English Partnerships, 2006 for the UK) rather than on its wider policy impacts. The only exceptions are Paull's (2008) case studies in the Northeast and Midwest of the US and Pauleit's (2005) research on Merseyside in England. The only study that adopted an extensive quantitative GIS approach to analyse brownfield regeneration in England was carried out by Longo and Campbell (2007), though their use of hedonic models aims to identify the drivers and determining conditions of brownfield development. This highlights the lack of comprehensive and detailed spatial analyses of policy impacts brought by brownfield development.

Notwithstanding the recent policy changes and the removal of national brownfield targets after nearly a decade's application, it is worth investigating the cumulative economic and community impacts of brownfield residential reuse on housing and neighbourhood change across England. While brownfield housing developments have impacts over all 
urban area, this study particularly focuses on the most deprived neighbourhoods. This is because the objective of regenerating deprived areas was deeply entrenched in the UK government's brownfield strategy (Dixon and Adams, 2008). The findings will also provide transferable lessons to other international contexts by offering a comprehensive assessment of the impacts and performance of brownfield residential reuse on achieving sustainable urban regeneration.

This study aims at addressing a number of key research questions:

- What are the most relevant and robust indicators for measuring economic and community impacts of residential brownfield regeneration?

- What types of economic and community impacts are identified over different time periods?

- What are the spatial patterns of residential brownfield regeneration impacts across different types of deprived neighbourhoods?

- Which are the impacts of increased density requirements on residential brownfield regeneration in different types of deprived areas?

The next section discusses the methodological issues of measuring policy impacts of brownfield residential development. The paper then analyses the nature and extent of different types of policy impact on different types of deprived neighbourhoods. Some conclusions are drawn on the effectiveness of brownfield redevelopment to accomplish the task of tackling deprivation 
problems and the relevance of these findings for the international debate about land use policies and urban regeneration.

\section{Methodology}

A major GIS analytical exercise was carried out to link datasets of different spatial and temporal scales to provide a consistent data structure for very fine-grained analysis of the pattern and scale of brownfield reuse and their relationships to different socio-economic indicators at the Super Output Area $^{2}$ (SOA) level. This section discusses the key concepts and methods used to ascertain brownfield reuse patterns and impacts.

\section{Brownfield -led regeneration and deprivation}

Large scale physical regeneration is often an important factor to break into the spiral of decline in inner cities and older industrial areas because businesses tend to hold back from investment in declining areas to avoid exploitation by free-riders (Bennett and Krebs, 1991). Physical blight caused by dereliction also bears a direct impact on the quality of living of local residents (Wong et al., 1991). Successive government policies have linked deprivation indicators with physical regeneration (Wong, 2006), for example, the '1981 Deprivation Index' (DoE, 1983) was used to inform the eligibility of local authorities to receive various physical regeneration grants including the Derelict Land Grant under the Urban Programme (DoE, 1983: para. 2). The brownfield land housing development target introduced in the late 1990s had since become an important component of the UK government's wider urban regeneration and housing policy agenda 
throughout the 2000s. This included area based initiatives such as the New Deal for Communities programme and the Neighbourhood Renewal Fund, which focused on socio-economic and physical regeneration. Other programmes such as the Housing Market Renewal programme tended to orientate towards physical regeneration to target areas of high vacancy rates and low housing demand.

The official Index of Multiple Deprivation (IMD) for England, first published in 2000, is the main index used to identify areas in need of regeneration. This index contains a living environment domain, but does not include any indicators on vacant and derelict sites (Deas et al, 2003). When developing the national brownfield strategy, English Partnerships (2008) demonstrated the strong spatial correlation between brownfield land location, as a sign of physical degradation, and socio-economic deprivation. The analysis linked the centroid of registered brownfield sites to its corresponding $^{3}$ deprivation index ranking. It shows that more than $20 \%$ of recorded brownfield sites were located inside the $10 \%$ most deprived areas of the IMD2007. This analysis, nevertheless, fails to examine the extent and location of regeneration activities taking place within each brownfield site and the resulting changes in the housing market and the living quality of local residents. Further research by Schulze Bäing (2010), with detailed site based data from the National Land Use Database (NLUD), found that residential brownfield reuse in the most deprived areas only reached comparable levels of less deprived areas under very buoyant property market conditions in 2005/06. 
In order to provide a temporal and detailed investigation of the brownfield regeneration process and its economic and community impacts, this study focuses on examining the time period of 2001 to 2008 as these are the years when the policy prioritising residential brownfield reuse was implemented. For analytical reasons, the research on residential brownfield development was further split into two periods, 2001-04 and 2005-08, because there was a clear shift in the uptake of brownfield land nationally in 2005 (see Wong and Schulze Bäing, 2010: 9).

\section{Measurement of brownfield residential development}

The main challenge to ascertain the policy impact of brownfield redevelopment is to collate and adjust data for consistent analysis across different spatial units over time. The National Land Use Database of Previously Developed Land and Buildings (NLUD-PDL), containing sitespecific information on vacant land and derelict land and buildings across England, was the key data source used in the analysis. The NLUD-PDL data is collected via an annual survey of local authorities and the first survey was conducted in 1998 by incorporating sites from the 1993 Derelict Land Survey. The data has been updated annually since 2001 .

Since not all local authorities are able to provide site-specific information for all sites, they are asked to provide a completeness estimate. The average completeness level was about $83 \%$ in the 2007 NLUD report. These completeness estimates were subsequently used to extrapolate figures to produce estimates for the number and amount of land cover of brownfield sites across England. With the survey-based data, the non-response of a few local authorities in different years means that certain adjustments and 
estimations have to be made for temporal analysis in this study. Another shortcoming of the data is that local authorities may not continue to provide information on sites that have been reused and left the database. Therefore, the analysis here only included individual sites that were reported to the NLUD with detailed information for 2001-04 and 2005-084.

\section{Different types of deprived neighbourhoods}

The characteristics and impact of brownfield housing development in the most deprived neighbourhoods were focused on the $10 \%$ and $20 \%$ most deprived areas based on the ranking of IMD2004. The use of IMD2004, which was largely constructed with 2001 data, is deemed as more appropriate than the latest IMD for the analysis because it provides a useful baseline to ascertain the government's brownfield development strategy, as the $60 \%$ brownfield target should have started to have an impact in 2002/03. Different deprived areas can vary significantly in terms of their role within wider housing markets, even though they might show similar levels of deprivation as measured by the IMD. The impact of residential brownfield reuse on different types of deprived neighbourhoods was examined with a dynamic functional typology (Robson et al, 2008). Based on the ranking of IMD2004, the $20 \%$ most deprived areas were classified into four area types according to their migration characteristics recorded in the 2001 Population Census. This rather novel typology, originally developed for an evaluation study of the National Neighbourhood Renewal Initiative, was subsequently adopted by the government in its national framework for regeneration in England (CLG, 2008). Knowing where people in the most deprived areas moved from, and moved to, provides a better grasp of the roles played by 
different neighbourhoods in the wider housing and labour markets, which is argued by the government as a more robust functional framework for examining neighbourhood change. The four dynamic neighbourhood types are:

- Escalator: in these areas, the incomers come from similar or more deprived areas and the out-movers go to less deprived areas. This neighbourhood type represents upward progression through housing and labour markets. About 27\% of their housing stock was flats in 2001. Examples are areas to the north of Sefton Park in Liverpool, to the east of Oxford Road (around Manchester University) in Manchester and Bordeslay in Birmingham (1,212 areas).

- Gentrifier: the social composition of these areas is altered by incomers from less deprived areas and out-movers to similar or more deprived locations. Flats constituted $36 \%$ of the housing stock in 2001. Examples are areas around Liverpool's Anglican Cathedral, the southern area of Manchester city centre and Castlefield and Brookfields in Birmingham (521 areas).

- Isolate: these are areas with fewer inward and outward migration links to other less deprived areas; hence they are socially more isolated. Only $24 \%$ of the housing stock in these areas was flats. Examples are Anfield in Liverpool, Moss Side in Manchester and Newtown in Birmingham (2,030 areas).

- Transit: most incomers and out-movers of these areas, typically young people moving onto the housing ladder, come from and go to less 
deprived areas. The housing stock in these areas was dominated by flats (41\% in 2001). Examples are areas in northern Liverpool city centre, the Northern Quarter in Manchester and Birmingham city centre (2,519 areas).

\section{Measuring policy impacts}

The preference for at least $60 \%$ of new housing to be built on brownfield land had an impact across many urban areas. Since there is a strong spatial correlation between the location of brownfield land and deprivation, brownfield residential development is therefore closely associated with regeneration programmes such as the New Deal for Communities, the Neighbourhood Renewal Fund and the Housing Market Renewal Pathfinder Programme. Hence, the analysis here focuses on the economic and community impacts of brownfield reuse on deprived areas. These impacts are ascertained via a number of indicators (an approach advocated by Dana, 2005): house price, planned residential density, population size, employment level and economic conditions.

Housing market performance, in terms of house price level and change, provides a good indication of brownfield redevelopment impact because the process is closely entwined with the objectives of improving housing supply and tackling low market demand in deprived neighbourhoods. A revitalized neighbourhood should see improved investment confidence and popularity, which tends to lead to an increase in property values. Property value was also used by Paull (2008) to measure the economic and community impacts of brownfield redevelopment in the US. Land Registry housing transaction data was used here to measure the level and change of house prices ${ }^{5}$ in areas 
with brownfield reuse activities. Through a GIS, house price data can be analysed in conjunction with the registered residential brownfield activities between 2001 and 2008. This allows us to assess the extent areas with residential brownfield reuse performed differently to those without such development.

The brownfield residential development policy was carried out in conjunction with an increase in density requirement. The Urban Task Force Report (1999) set out to accommodate an extra 4 million new households in towns and cities over the 25 year period. The figure was later revised upwards to an annual target of 240,000 by 2020 . In order to achieve these numbers under the constraint of land supply, successive planning policy guidance documents (DETR, 2000b; CLG, 2006) stipulated densities for new homes of 30-50 dwellings per hectare (ha), and even higher in urban areas with good public transport links. However, this new form of high density urbanization has been criticised by some as 'new urban colonialism' (Atkinson and Bridge, 2005) and 'new build gentrification' (Davidson and Lees, 2005) that brings destructive and unsettling changes within the neighbourhood. The potential impact of high density brownfield development was examined via the planned dwelling density for those sites that have been redeveloped as reported in previous NLUD surveys (in some cases the planned density could differ from the actual build density).

It would be ideal if the official IMD could track changes in the deprivation level brought by brownfield redevelopment in different neighbourhoods. However, many indicators used to construct the IMD are based on administrative and survey data estimates (Tomlinson and Kelly, 2003) 
which are not sufficiently robust to perform temporal change analysis of small areas (SDRC, 2004; Wong, 2006). Since there is little scope for making meaningful comparison of successive deprivation indices, other more reliable indicators such as population change (e.g. Coombes and Raybould, 1989; Wong, 2002) and employment level change (e.g. Green and Champion, 1989; Pieda, 1995; Paull, 2008) as well as the more direct measure of income deprivation change (e.g. BERR, 2009) are used.

Population change was measured with the Office for National Statistics' postcensal small area population estimates. Although being classified as experimental statistics, this data source provides a good indication of population change in most areas. For the change analysis of employment and income, the Economic Deprivation Index (EDI) was used. The EDI, consists of the employment and income domains of the IMD, is based on government benefit claimant counts (rather than survey estimates) and thus provides a robust means to track changes in the level of economic deprivation. EDI data is available annually between 1999 and 2005. The analysis here focuses on changes in the mean rank of the EDI and its associated income and employment domains between 2001 and 2005.

These indicators were analysed to ascertain whether brownfield residential development has brought any economic and community impacts to the deprived neighbourhoods, and whether such impacts vary between different types of neighbourhoods. While other brownfield regeneration studies adopted hedonic analysis (e.g. Adams and Watkins, 2009; Longo and Campbell, 2007) to develop regression models to estimate the determining conditions of successful brownfield reuse, this study measures the impact of 
brownfield reuse directly with the identified indicators. Furthermore, oneway analysis of variance (ANOVA) is used to perform statistical testing on the indicator to find out whether or not the mean values of different neighbourhood groups are all equal. The ANOVA statistical procedures compare the within group variations and the between group variations to test whether significant differences exist between different groups on that particular indicator.

\section{Impact of Brownfield Residential Reuse in Deprived Neighbourhoods}

Brownfield redevelopment take-up

The NLUD figures in Table 1 show the dynamics of brownfield development in deprived areas. A total of 2,833 hectares of brownfield land was recycled for housing development in the $20 \%$ most deprived neighbourhoods between 2001 and 2008. The number of sites and land area for brownfield housing development in England had decreased in the period 2005-08 when compared to 2001-04. This was probably due to the exhaustion of the most viable and profitable brownfield land supply ${ }^{6}$. Nevertheless, in the most deprived neighbourhoods, the development trend was reversed with more sites and land area recycled for housing use in the period 2005-08. About 24\% of England's brownfield land reused for housing development was located in the $20 \%$ most deprived neighbourhoods in 2005-08, compared to $17 \%$ in 2001-04. Indeed, the amount of recycled brownfield land for housing use increased most rapidly (by $25 \%$ ) in the $10 \%$ most deprived neighbourhoods between these two periods. 
Insert table 1

Regions in England with the larger share of population in deprived areas also have a larger share of 'vacant and derelict' land stock according to Land Use Change Statistics (LUCS): with a strong statistical relationship (Pearson's product-moment correlation $\mathrm{r}=0.80, p<0.01$ ) in the $10 \%$ most deprived areas; and a even stronger correlation $(\mathrm{r}=0.85, p<0.01)$ in the $20 \%$ most deprived areas.

A more detailed investigation of different types of deprived areas in Table 1 shows that most brownfield land recycled for residential use was concentrated in Isolate and Transit areas, which partly reflects the fact that $72 \%$ of the $20 \%$ most deprived neighbourhoods fell into these two categories. Gentrifiers $(9.8 \%)$ and Isolates $(36.1 \%)$ were doing relatively well in their share of recycling brownfield land in the 2001-04 period, though only Isolates $(45.3 \%)$ continued the momentum during 2005-08. Meanwhile, the activities in Transit areas (with a $41.2 \%$ share) accelerated in 2005-08. Interviews with planners and regeneration experts in the North West of England (see Schulze Bäing, 2009) confirmed that developers tended to pick areas with stronger gentrification potential and the highest profit yields in the earlier period. When the more desirable land ran out, together with the incentives of government regeneration initiatives, developers started venturing into the wider market of Transit and Isolate areas. It is also interesting to note that the level of residential reuse of longterm brownfield land, which is deemed as difficult to shift, shows very similar patterns to those of all brownfield reuse in different types of neighbourhoods. 


\section{Housing market}

In spite of the absolute increase in the price differential between the most deprived areas and the average in England (Table 2), the relative house price gap between them has narrowed since 2001 . This was due to a relatively higher level of house price increase between 2001 and 2008 in deprived areas: an increase of $102 \%$ and $96 \%$ respectively in the $10 \%$ and $20 \%$ most deprived neighbourhoods. Between 2005 and 2008, bearing in mind that there was a major slow down in the property market, the level of house price increase in the deprived neighbourhoods actually outperformed that of the English average. When examining price changes in terms of the presence/absence of brownfield reuse activities during 2001-08, the mean price increase across England only marginally varied. However, the increase in prices was stronger in areas with brownfield reuse $(61 \%)$ than those without (57.6\%) during 2001-05, but this change reversed during 2005-08 when areas without brownfield reuse (16.6\%) performed better than areas with such redevelopment $(13.7 \%)$. ANOVA tests confirm that the price change differentials between the presence/absence of brownfield reuse are statistically significant for the periods of 2001-05, 2005-08 and 2001-08.

Insert table 2

The analysis turns to examine to what extent the strong market performance in the deprived areas was related to brownfield residential development. While the absolute price levels of the most deprived areas with brownfield reuse are found lower than areas without such activities, the relative house price performance was nevertheless stronger in deprived areas with 
brownfield development (an increase of $113.5 \%$ and $105.7 \%$ respectively in the $10 \%$ and $20 \%$ most deprived areas) throughout 2001-08. This was mainly due to the strong housing market performance of brownfield housing development between 2001 and 2005, though the trend had reversed since 2005. The differentials in house price change between areas with and without brownfield residential development were all statistically significant for both 10 and $20 \%$ most deprived areas.

The level of house price inflation varied between different types of deprived neighbourhoods that had brownfield reuse (see Table 2). Isolate areas had the highest level of house price inflation of $122 \%$, rising from a very low level of $£ 53,000$ to $£ 118,000$ during 2001-08. On the other hand, Transit areas had the lowest level of house price inflation (93\%) when compared to the other neighbourhood types, which was partly related to the fact that these areas commanded the highest house price level among the most deprived locations. What is counter-intuitive is that neither the house price level nor the relative price change (99\%) was that high in Gentrifier areas. This suggests that gentrification has not necessarily created any major negative impact on housing affordability in these neighbourhoods (as they tended to be small enclaves of development) when compared to other deprived neighbourhood types.

As many brownfield housing development schemes are very high density apartments and flats, it is important to specifically examine the patterns of house price changes for flats. The analysis of housing stock distribution with the 2001 Census data shows that about $19 \%$ of households in England lived in flats. Within the $20 \%$ most deprived areas (IMD 2004) the share of 
households living in flats was much higher (32.5\%), though there were great variations among different types of neighbourhoods. While the proportion was lower in Isolates (24\%) and Escalators (27\%), the figure was higher in Gentrifier (36\%) and Transit areas (41\%), reflecting the different functional role that these areas play within the wider housing markets. On the whole, the price levels of flats were slightly lower than the average prices of all house types in the four deprived neighbourhood groups; which were also true in terms of house price inflation levels between 2001 and 2008. While Isolates gained most from the average house price inflation during 2001-08, Escalators $(101 \%)$ had the highest level of price increase for their flat markets. It is also noticeable that higher levels of house price appreciation were found for flats in Transit (15.6\%) and Gentrifier (13.5\%) areas during 2005-08 than the average house price increase in these areas $(9.6 \%$ and $11.6 \%$ respectively).

Planned residential density

According to LUCS, the overall housing density in England increased from 31 to 42 dwellings per hectare when comparing the periods of 2001-04 with 2005-08. The figures were higher for all previously developed land, with an increase from 35 to 48 dwellings per hectare; and stark increases were found in vacant and derelict land as the average density rose from 39 to 68 dwellings per hectare. Since the LUCS are spatially aggregated data, the NLUD data was used to further examine the density patterns in the most deprived areas.

Insert figure 1 
Figure 1 shows that there was an increase in planned dwelling density of reused brownfield sites since 2001, though this trend halted in 2007 following the downturn in the property market. It is interesting to note that the level of planned density had been much higher in the most deprived neighbourhoods (98 and 93 dwellings per hectare for the $20 \%$ and $10 \%$ most deprived neighbourhoods respectively) than the England average (59 per hectare) during 2001-08. Nonetheless, the patterns of planned density change tended to be more erratic in the most deprived areas: with a decrease in the early 2000s, followed by a major increase in 2005 and 2006 and then a decline since 2007 .

Among the deprived neighbourhoods, Transits had the highest planned density, with 96.5 dwellings per hectare during 2001-04 and a sharp increase to 147.8 during $2005-08$. These areas tend to associate with rental locations for students and young professionals in high rise flats. When considering the large amount of brownfield land uptake and the extreme high density of residential development, Transit areas have undergone major physical transformation throughout the last decade. Another neighbourhood type that also had very high density development is the Gentrifier (a rise from 76.8 to 117 dwellings per hectare between the two periods), which was related to their market potential as up and coming locations. Despite their good performance in recycling a large amount of brownfield land, the housing density in Isolate areas tended to be at the lower end of the spectrum (a slow rise from 60.1 to 74.9 dwellings per hectare). This is attributed to the fact that new build schemes in these areas tended to focus more on the renewal of family homes for existing residents rather than 
building high rise flats. Escalators also had lower density of development in 2001-04 (55.8 dwellings per hectare), though it rose to a higher level (90.2) since the latter half of the 2000s. The findings suggest that brownfield housing development has intensified the already high densities in Transit and Gentrifier areas by further increasing the stock of flats.

\section{Population growth}

One of the government's brownfield regeneration objectives was to bring back people to live in town and cities. The data in Table 3 shows that residential brownfield reuse is statistically related to population growth across all neighbourhood types. Between 2001 and 2007, the total population had increased by $6.6 \%$ and $7.2 \%$ respectively in the most deprived $10 \%$ and $20 \%$ areas with brownfield activities; while the figures were $2.6 \%$ and $2.4 \%$ for these areas without brownfield development. Transit areas $(4.5 \%)$ experienced most (estimated) population growth between 2001 and 2007, which was followed by Gentrifiers (3.5\%). On the other hand, both Isolate (0.9\%) and Escalator (1.6\%) areas had lower levels of population growth.

Insert table 3

There are, however, marked (statistically significant) differences in terms of the level of population growth in areas that had benefited from brownfield development across all neighbourhood types. Despite the higher take-up rate of brownfield development in Isolates (see Table 1), it had the lowest level of population growth $(3.8 \%)$. This was largely related to the low density 
development that focused more on improving the living conditions of the original residents rather than on attracting new migrants.

\section{Employment and income}

Economic change was gauged by tracking the shift of the EDI mean rank (see Table 3). The level of improvement in economic deprivation conditions between 2001 and 2005 tended to be higher (statistically significant) in the $20 \%$ most deprived areas (an improvement of 320 EDI rank) and all neighbourhoods (an improvement of 132 rank) that had benefited from brownfield housing development. However, such differentials were found statistically insignificant in the top $10 \%$ extremely deprived areas.

These changes were very much related to the inflow of new residents to the neighbourhoods taking up the newly developed housing units on brownfield land. These residential dynamics of population growth can also explain the much stronger improvement in the employment deprivation rankings of areas with residential brownfield reuse, and some improvement over the income domain. The findings suggest that brownfield redevelopment did not seem to improve the economic conditions of the extremely deprived neighbourhoods. However, this could be related to the fact that developers tended to cherry pick the best locations for development first (see Table 1), thus more brownfield reuse activities in the $10 \%$ most deprived areas were actually taking place during the latter half of the decade. Since the EDI data is only available up to 2005 , the improvement in the $10 \%$ most deprived areas was probably not being reflected in the 2001-05 change analysis and should be followed up in future research. 
The analysis in Table 3 clearly shows that most improvement in the overall EDI ranking was found in Gentrifiers, which also experienced high levels of brownfield reuse activities during 2001-05. Despite the fact that employment deprivation in Transit areas had got relatively worse, it is worth noting that those areas with brownfield reuse activities had shifted their position significantly in a positive direction. Isolates also made major improvements in their relative position on income and employment conditions, though brownfield activities were not found to make any significant difference in improving their deprivation rankings. Escalators experienced the least improvement in terms of income deprivation mean rank and the overall EDI, and were actually getting worse in the employment deprivation ranking. Similar to Isolates, brownfield redevelopment did not have much of a booster effect to improve the economic conditions in the Escalator group.

\section{Which deprived neighbourhoods benefit most?}

The analysis shows that the uptake of brownfield land (including difficult to shift stock) for housing development in areas with severe deprivation problems had been high since 2001. These redevelopment activities had successfully reignited the housing market in these neighbourhoods and led to house price increases. There had also been a relatively higher level of improvement in the EDI and its associated income and economic domains in areas with brownfield residential regeneration activities, specifically in Gentrifier and Transit neighbourhoods. However, different neighbourhood types exhibited different characteristics of change. 
- Gentrifiers: these areas performed best in terms of the uptake of brownfield land in the early 2000s and the improvement in their EDI. This was related to the high level of population growth and thus a change in the social composition of these areas by the incomers. However, it is surprising to find that the overall house price and relative house price change in this group were not as high as in other deprived area types. This was partly related to the fact that Gentrifier areas tended to have small enclaves of development.

- Transits: these areas tended to have high levels of brownfield development and, since the mid-2000s, house building was at extremely high density. Transit areas also experienced high population growth and improvement in their economic deprivation ranking. These areas, however, did not experience the highest level of house price inflation as they commanded relatively high price levels throughout the 2000s.

- Isolates: the new residential development in these areas was not built at such high density levels as seen in Gentrifier and Transit neighbourhoods. The relatively low density of development also means that the population was stabilised rather than showing much growth during 2001-07. Nevertheless, this group showed the highest level of house price inflation, from an extremely low base, when compared to other deprived areas. It is also intriguing to note that while major improvement in the EDI was found in Isolates with brownfield activities, similar improvement was also found in areas without brownfield development. This suggests that the improvement in economic deprivation cannot be purely attributed to brownfield 
development during 2001-05. More importantly, residential brownfield development accelerated in the latter part of the 2000s, but the EDI data is not yet available after 2005 to capture the impact.

- Escalators: this area group tended to perform well in terms of house price increases, but more modestly in terms of estimated population growth and had the least improvement in the EDI and income deprivation rankings. This partly reflected the fact that Escalator neighbourhoods tended to be located in more popular locations and had a much lower level of brownfield residential reuse in comparison with other area types. This, together with the relatively lower density of development, means that the impact of brownfield residential development had been relatively less significant.

\section{Conclusion}

Unlike previous case-study based research on the socio-economic impact of brownfield regeneration, this study used the extensive survey data of the NLUD-PDL to identify impacts across England and within different types of deprived areas. A number of key findings are identified:

- The uptake of brownfield land across different types of deprived neighbourhoods for housing development had been high, even in areas with long term vacant and derelict land. The market for flats in particular has grown since the mid 2000s.

- The new housing developments had altered the socio-economic dynamics of their neighbourhoods, with population growth evident in the most deprived areas between 2001 and 2007. 
- These areas had seen improvements in economic and income deprivation rankings when compared to neighbourhoods without brownfield housing development.

- The analysis of brownfield reuse trends and patterns in the four types of deprived neighbourhoods suggests mixed outcomes and different development trajectories.

The analysis shows that high levels of brownfield reuse activities had successfully accomplished the objective of injecting dynamics into the housing markets in the most deprived areas, particularly the market for flats, since the mid 2000s. This shift was related to the spatially targeted activities of the National Neighbourhood Renewal Initiatives and the Housing Market Renewal Pathfinder programmes.

In terms of economic impacts, the outcomes were mixed. While major improvement in the EDI was found in the $10 \%$ most deprived areas as well as in Isolates and Escalators, similar improvement was also found in areas with and without brownfield development. The mixed messages from the analysis are also closely associated with the socio-demographic change of the neighbourhoods. Gentrifiers and Transits had the highest level of population growth and their EDI rankings shifted significantly in comparison with similar neighbourhoods without brownfield regeneration activities; while significant change in population growth and EDI rankings were not found in Isolate and Escalator areas. This suggests that the improvement in economic deprivation is associated with the process of 'social upgrading' by the incoming new residents of brownfield housing developments (Davidson and Lees, 2005). 
The positive signs of brownfield development in the most deprived neighbourhoods imply that they had undergone some major restructuring process in their housing markets and the wider neighbourhoods. These broad patterns suggest signs of policy success in regenerating declining neighbourhoods through brownfield residential development, though this brought with it negative impacts on local housing affordability as well as changing the socio-economic dynamics and the physical fabric of the neighbourhoods. This is particularly true in neighbourhoods that have undergone major socio-spatial restructuring brought by new forms of high density housing schemes. Critics argue that such high density urbanization brings destructive and unsettling changes within the neighbourhood, which are coined as 'gentrification-induced social change' (Davidson and Lees, 2005). However, it is very likely that the dynamics of change vary between neighbourhoods and it would therefore be difficult to use a small number of case studies to derive clear conclusions about the interactive outcomes brought by brownfield residential reuse.

This paper has a clear focus on England. Despite the specific housing market conditions and planning system in England, the findings can shed light on the international debate on the application and performance of brownfield development strategy to achieve the objectives of urban containment and sustainable regeneration. The findings suggest that to some extent such policies have helped to reduce greenfield development rates and have contributed towards urban regeneration. While there are signs of policy success, they can also be interpreted as a function of the interaction of policy and housing market dynamics - with developers selecting areas with 
greatest brownfield development potential, especially when there has been much less prospect of obtaining planning permission for greenfield development.

The use of NLUD and other data at micro spatial scales in this study has proved to be robust to establish policy impacts, though the process of integrating different databases into a coherent data structure was challenging. The use of ANOVA method was very valuable as the statistically testing goes beyond the superficial mean values by comparing the variations between and within different neighbourhood groups. However, the analysis here only provides a snapshot of what has happened to the neighbourhoods with different socio-economic dynamics in the baseline year of 2001, but is unable to show what has happened to the residents living in these neighbourhoods in later years due to the lack of updated migration and population statistics at such micro level. These issues could be re-examined when the 2011 Population Census data becomes available, but meanwhile, further research can only resort to the collection of primary data via a case study methodology.

\section{Acknowledgement}

Removed for review 


\section{References}

Adams D. (2004) The changing regulatory environment for speculative house building and the construction of core competencies for brownfield development, Environment and Planning A, 36(4), 601-624.

Adams, D. and Watkins, C. (2009) Brownfield market signals: greenfield housing land supply and the viability of brownfield housing development. London: Campaign to Protect Rural England.

Atkinson, R. and Bridge, G. (2005) The New Urban Colonialism: Gentrification in a Global Context. London: Routledge.

Barker, K. (2003) Review of housing supply: securing our future needs, Interim Report - Analysis. London: HM Treasury.

Bennett, R. J. and Krebs, G. (1991) Local Economic Development: publicprivate partnership initiatives in Britain and Germany. London: Belhaven Press.

BERR [Department for Business Enterprise and Regulatory Reform] (2009) Regional Economic Performance Indicators and Regional Competitiveness \& State of the Regions. London: BERR. 
Cameron, S. (2006) From Low Demand to Rising Aspirations: Housing Market Renewal within Regional and Neighbourhood Regeneration Policy, Housing Studies, 21(1), 3-16.

CLG [Department for Communities and Local Government] (2006) Planning Policy Statement 3 (PPS3), Housing. London: CLG.

CLG (2008) Transforming Places; Changing Lives: A framework for regeneration. London: CLG.

CLG (2010a) Land Use Change Statistics (England) 2009 - provisional estimates. London: CLG.

CLG (2010b) Previously Developed Land and Density - statement by the Minister for Decentralisation. Retrieved 30/03, 2011, from http://www.communities.gov.uk/statements/corporate/pps3statement.

CLG (2011) Planning and the Budget. London: CLG. http://www.communities.gov.uk/newsstories/planningandbuilding/1872022

Coombes, M. and Raybould, S. (1989) Developing a Local Enterprise Activity Potential Index, Built Environment, 14(2), 107-117.

Dana, D. A. (2005) State brownfields programme as laboratories for democracy, NYU Environmental Law Journal, 14(1), 86-107. 
Davidson, M. and Lees, L. (2005) New-build 'gentrification' and London's riverside renaissance, Environment and Planning A, 37, 1165-1190.

Deas, I., Robson, B., Wong, C. and Bradford, M. (2003) 'Measuring neighbourhood deprivation: a critique of the Index of Multiple Deprivation', Environment and Planning C, 21(6), 883-903.

DETR [Department of Environment, Transport and the Regions] (2000a) Our Towns and Cities: The Future - Delivering and Urban Renaissance. London: DETR.

DETR (2000b) Planning Policy Guidance Note 3. London: DETR.

Dixon, T. J. (2006) Integrating sustainability into brownfield regeneration: rhetoric or reality? An analysis of the UK development industry, Journal of Property Research, 23(3), 237-267.

Dixon, T. and Adams, D. (2008) Housing supply and brownfield regeneration in a post-Barker World: is there enough brownfield land in England and Scotland? Urban Studies, 45(1), 115-139.

Dixon, T.; Pocock, Y. and Waters, M. (2006) An analysis of the UK development industry's role in brownfield regeneration, Journal of Property Investment and Finance, 24(6), 521-541. 
DoE [Department of the Environment] (1983) Urban deprivation, Information Note 2, Inner City Directorates. London: DoE.

Dull, M. and Wernstedt, K. (2010) Land recycling, community revitalisation, and distributive politics: an analysis of EPA Brownfields Program Support, Policy Studies Journal, 38(1), 119-141.

English Partnerships (2003) Towards a National Brownfield Strategy, Research Findings for the Deputy Prime Minister. London: English Partnerships.

English Partnerships (2006) The Brownfield Guide: a practitioners' guide to land reuse in England. London: English Partnerships.

English Partnerships (2008) Brownfield Land and Deprivation, retrieved 23/03/09 from http://www.englishpartnerships.co.uk/nlud.htm

Greenhalgh, P. and McCafferty, A. (1996) Derelict land reclamation and English Partnerships - shedding light on the new regime, Property Management, 14(3), 10-16.

Green, A. and Champion, A. (1989) Measuring local economic performance: methodology and applications of the Booming Towns Approach, Built Environment, 14(2), 78-95. 
Greenberg, M.; Lowrie, K.; Mayer, H.; Tyler Miller, K. and Solitare, L. (2001) Brownfield redevelopment as a smart growth option in the United States, The Environmentalist, 21, 129-143.

HALL, P. (1974) The Containment of Urban England, The Geographical Journal, 140(3), 386-408.

Harrison, B. (2010) Finding a Role? The United Kingdom 1970-1990. Oxford: Clarendon Press.

HM Government (2005) Securing the future: delivering UK sustainable development strategy. London: DEFRA.

Longo, A. and Campbell, D. (2007) What are the determinants of brownfields regeneration? An analysis of brownfields in England, paper presented at the Conference on the Science and Education of Land Use, The Westin, Washington DC, September 24-26 (www.qub.ac.uk/aflu)

National Round Table on Environment and the Economy (2003) Cleaning up the past, building the future, a national brownfield redevelopment strategy for Canada, National Round Table on Environment and the Economy, Ontario, Canada. (http://www.nrtee-trnee.com) 
Nuissl, H. and Rink, D. (2005) The "production" of urban sprawl in eastern Germany as a phenomenon of post-socialist transformation, Cities, 22(2), 123-134.

ODPM [Office of the Deputy Prime Minister] (2003) Sustainable Communities: building for the future. London: ODPM.

Oliver, L, Ferber, U, Grimski, D, Millar, K and Nathanail, P. (2005) The Scale and Nature of European Brownfields. In CABERNET. Proceedings of CABERNET 2005: The International Conference on Managing Urban Land, Edited by: Oliver, L, Millar, K, Grimski, D, Ferber, U and Nathanail, P. Nottingham: Land Quality Press.

Pauleit, S., Ennos, R., et al. (2005) Modelling the environmental impacts of urban land use and land cover change - a study in Merseyside, UK, Landscape and Urban Planning, 71(2-4), 295-310.

Paull, E. (2008) The Environmental and Economic Impacts of Brownfields Redevelopment, Northeast-Midwest Institute (www.nemw.org).

Pieda (1995) Local economic audits: a practical guide, a final report to the Employment Department.

Raco, M. and Henderson, S. (2006) Sustainable urban planning and the brownfield development process in the United Kingdom: Lessons from the 
Thames Gateway, Local Environment: The International Journal of Justice and Sustainability, 11(5), 499 - 513.

Robson, B.; Lymperopoulou, K. and Rae, A. (2008) People on the move: exploring the functional roles of deprived neighbourhoods, Environment and Planning A, 40(11), 2693-2714.

Schulze Bäing, A. and Syms, P. (2009) Brownfield regeneration and social change. Project report for the Homes and Communities Agency, Warrington.

Schulze Bäing, A. (2010) Target-driven brownfield reuse - a benefit for deprived areas? A spatial analysis of brownfield reuse patterns in England's core city regions, Journal of Urban Regeneration and Renewal, 3(3), 290300.

SDRC [Social Disadvantage Research Centre] (2004) Understanding neighbourhood change: challenges and potential for using and combining data at neighbourhood level, paper prepared by SDRC, University of Oxford for the ESRC/ODPM 'Understanding Neighbourhood Change' seminar, at Central Hall, London, 30 March.

Spaans, M.; Janssen-Jansen, L. and van der Veen, M. (2011) Marketoriented compensation instruments: lessons to Dutch urban redevelopment, Town Planning Review, 82(4): 425-440. 
Tomlinson, M. and Kelly, G. (2003) What's the use of the Noble index? Theories, methods and applications, in: E. McLaughlin and G. Kelly (Eds.) Anti-Poverty Strategies in Ireland, North and South. Belfast, Department for Social Development and Social Security Research, Queen's University of Belfast.

UHEL, R. (2006) Urban sprawl in Europe: the ignored challenge (Copenhagen: European Environment Agency).

Urban Task Force (1999) Towards an Urban Renaissance, London: E \& FN Spon.

Wernstedt, K.; Meyer, P.B. and Alberini, A. (2006) Incentives for private residential brownfields development in US urban areas, Journal of Environmental Planning and Management, 49(1), 101-119.

Wong, C. (2002) Developing indicators to inform local economic development in England, Urban Studies, 39(10), 1833-1863.

Wong, C. (2006) Quantitative Indicators for Urban and Regional Planning: the Interplay of Policy and Methods, Royal Town Planning Institute Library Book Series. London: Routledge. 
Wong, C.; Coombes, M. and Raybould, S. (1991) The environmental

quality of residential neighbourhoods: a town planning application of GIS,

Town Planning Review, 62(3), 369-373.

Wong, C. and Schulze Bäing, A. (2010) Brownfield residential redevelopment in England: what happens to the most deprived neighbourhood? York: Joseph Rowntree Foundation.

Yelling, J. (2000) The incidence of slum clearance in England and Wales, 1955-85, Urban History, 27(2), 234-254

${ }^{1}$ Defined in Section 101 of the Comprehensive Environmental Response, Compensation, and Liability Act of 1980 (42 U.S.C. 9601)

${ }^{2}$ SOAs, intermediate in size between Output Areas and Local Authorities, are of consistent size across the country. They were built with 2001 Census data for the collection and publication of small areas statistics. There are two layers of SOA and each layer nesting inside the layer above. (http://www.idea.gov.uk/idk/core/page.do?pageId=7175806)

${ }^{3}$ IMD 2007 ranking are produced for the lower layer SOAs. There are 32,482 lower layer SOAs in England and each has a minimum population of 1000. See http://www.ons.gov.uk/about-statistics/geography/products/geog-products-area/namescodes/soa/index.html

${ }^{4}$ The analysis of NLUD-PDL here only included authorities that have reported their data for either 2003 or 2004 and for either 2007 or 2008. As a result, these local authorities were excluded from the analysis: Allerdale, Aylesbury Vale, Barrow-in-Furness, Bracknell Forest, Bradford, Broadland, Broxtowe, Camden, Caradon, City of London, Colchester, Derbyshire Dales, Dudley, East Devon, Eastbourne, Erewash, Gateshead, Greenwich, Hart, High Peak, Isles of Scilly, Leeds, Lewes, Maldon, North Shropshire, North Tyneside, North Wiltshire, Nuneaton and Bedworth, Oadby and Wigston, Ryedale, South Oxfordshire, St. Edmundsbury, Teesdale, Torridge, Vale of White Horse, and West Devon.

${ }^{5}$ The geography chosen for this analysis is medium layer super output areas (MSOA). There are 6,780 MSOAs in England and they were built from groups of Lower Layer SOAs and constrained by the 2003 local authority boundaries used for 2001 Census outputs. They have a minimum population of 5,000. Smaller geographies such as lower layer super output areas or postcode sectors were not used for house price analysis because it would have contained too many cases with no registered transactions and made the tracking of change less robust.

${ }^{6}$ When interpreting these absolute figures, one has to consider that the 2001 and 2002 data includes some sites that have been reused in the period since the previous NLUD in 1998. 
Table 1 Brownfield land residential reuse in the most deprived neighbourhoods

\begin{tabular}{|c|c|c|c|c|c|c|c|c|}
\hline & \multicolumn{4}{|c|}{ 2001-2004 } & \multicolumn{4}{|c|}{$2005-2008$} \\
\hline & \multicolumn{2}{|c|}{ Reused sites } & \multicolumn{2}{|c|}{ Reused land (ha) } & \multicolumn{2}{|c|}{ Reused sites } & \multicolumn{2}{|c|}{ Reused land (ha) } \\
\hline England & \multicolumn{2}{|c|}{$\begin{array}{c}9834 \\
(100 \%)\end{array}$} & \multicolumn{2}{|c|}{$\begin{array}{c}8259 \\
(100 \%)\end{array}$} & \multicolumn{2}{|c|}{$\begin{array}{c}8668 \\
(100 \%)\end{array}$} & \multicolumn{2}{|c|}{$\begin{array}{c}6479 \\
(100 \%)\end{array}$} \\
\hline $\begin{array}{l}20 \% \text { most } \\
\text { deprived } \\
\text { IMD04 }\end{array}$ & \multicolumn{2}{|c|}{$\begin{array}{c}1702 \\
(17.3 \%)\end{array}$} & \multicolumn{2}{|c|}{$\begin{array}{c}1288 \\
(15.6 \%)\end{array}$} & \multicolumn{2}{|c|}{$\begin{array}{c}2053 \\
(23.7 \%)\end{array}$} & \multicolumn{2}{|c|}{$\begin{array}{c}1532 \\
(23.7 \%)\end{array}$} \\
\hline $\begin{array}{l}10 \% \text { most } \\
\text { deprived } \\
\text { IMD04 }\end{array}$ & \multicolumn{2}{|c|}{$\begin{array}{c}881 \\
(9.0 \%)\end{array}$} & \multicolumn{2}{|c|}{$\begin{array}{c}723 \\
(8.8 \%)\end{array}$} & \multicolumn{2}{|c|}{$\begin{array}{c}1178 \\
(13.6 \%)\end{array}$} & \multicolumn{2}{|c|}{$\begin{array}{c}905 \\
(14.0 \%)\end{array}$} \\
\hline & & & & & & & & \\
\hline \multirow[t]{2}{*}{$\begin{array}{l}\text { Deprived } \\
\text { area types }\end{array}$} & \multicolumn{2}{|c|}{$\begin{array}{l}\text { land reused } \\
2001-04\end{array}$} & \multicolumn{2}{|c|}{$\begin{array}{c}\text { land reused } \\
2005-08\end{array}$} & \multicolumn{2}{|c|}{$\begin{array}{l}\text { long-term land } \\
\text { reused 2001-04 }\end{array}$} & \multicolumn{2}{|c|}{$\begin{array}{l}\text { long-term land } \\
\text { reused 2005-08 }\end{array}$} \\
\hline & ha & $\%$ & ha & $\%$ & ha & $\%$ & ha & $\%$ \\
\hline $\begin{array}{l}\text { Escalator } \\
19.3 \%\end{array}$ & 214 & 16.2 & 257 & 9.5 & 109.4 & 14.5 & 40.4 & 9.5 \\
\hline $\begin{array}{l}\text { Gentrifier } \\
8.3 \%\end{array}$ & 130 & 9.8 & 104 & 4.0 & 70.1 & 9.3 & 16.9 & 4.0 \\
\hline $\begin{array}{l}\text { Isolate } \\
32.3 \% \\
\end{array}$ & 479 & 36.1 & 492 & 45.3 & 295.3 & 39.2 & 193.7 & 45.3 \\
\hline $\begin{array}{l}\text { Transit } \\
40.1 \%\end{array}$ & 504 & 38.0 & 652 & 41.2 & 278.4 & 37.0 & 176.1 & 41.2 \\
\hline $\begin{array}{l}\text { Total } \\
100 \%\end{array}$ & 1328 & 100.0 & 1505 & 100.0 & 753.2 & 100.0 & 427.2 & 100.0 \\
\hline
\end{tabular}

Source: NLUD-PDL

Note: These figures cover only those local authorities included in this analysis and those sites where detailed site data was reported. 
Table 2 House price level and change

\begin{tabular}{|c|c|c|c|c|c|c|c|c|c|c|}
\hline & \multicolumn{10}{|c|}{ Mean house prices $(\mathfrak{f})$} \\
\hline & \multicolumn{3}{|c|}{\begin{tabular}{|l|}
2001 \\
\end{tabular}} & \multicolumn{3}{|c|}{2005} & \multicolumn{4}{|c|}{2008} \\
\hline & All & $\mathrm{BF}$ & No BF & All & $\mathrm{BF}$ & No BF & All & & & No BF \\
\hline England & 121769 & 117714 & 129082 & 192274 & 189504 & 203368 & 220310 & & 464 & 237028 \\
\hline $\begin{array}{l}20 \% \text { most } \\
\text { deprived IMD04 }\end{array}$ & 78536 & 68382 & 82436 & 133065 & 124249 & 136449 & 154211 & & 660 & 159414 \\
\hline \multirow[t]{4}{*}{$\begin{array}{l}10 \% \text { most } \\
\text { deprived IMD04 }\end{array}$} & 67780 & 61530 & 70491 & 118087 & 114940 & 119450 & 137125 & & 370 & 139618 \\
\hline & \multicolumn{10}{|c|}{ Mean house price change \% } \\
\hline & \multicolumn{3}{|c|}{$2001-2005$} & \multicolumn{3}{|c|}{$2005-2008$} & \multicolumn{4}{|c|}{ 2001-2008 } \\
\hline & All & $\mathrm{BF}$ & No BF & All & $\mathrm{BF}$ & No BF & All & & $\bar{F}$ & No BF \\
\hline England & 57.9 & $61.0 * *$ & $57.6 * *$ & 14.6 & $13.7 *$ & $16.6^{*}$ & 80.9 & & ** & $83.6^{* *}$ \\
\hline $\begin{array}{l}\text { 20\% most deprived } \\
\text { IMD04 }\end{array}$ & 69.4 & $81.7 * *$ & $65.5^{* *}$ & 15.9 & $13.2 * *$ & $16.8 * *$ & 96.4 & & $7 * *$ & $93.4 * *$ \\
\hline $\begin{array}{l}10 \% \text { most deprived } \\
\text { IMD04 }\end{array}$ & 74.2 & $86.8 * *$ & $69.5 * *$ & 16.1 & $14.3 *$ & $16.9 *$ & 102.3 & \multicolumn{2}{|c|}{$113.5^{* *}$} & $98.1 * *$ \\
\hline & $\begin{array}{c}2001 \\
(\mathfrak{f})\end{array}$ & \multicolumn{2}{|c|}{$\begin{array}{c}2005 \\
(\mathfrak{f})\end{array}$} & $\begin{array}{c}2008 \\
(\mathfrak{f})\end{array}$ & \multicolumn{2}{|c|}{$\begin{array}{c}2001-05 \\
\% \text { change }\end{array}$} & \multicolumn{2}{|c|}{$\begin{array}{c}2005-08 \\
\% \text { change }\end{array}$} & \multicolumn{2}{|c|}{$\begin{array}{c}2001-08 \\
\% \text { change }\end{array}$} \\
\hline \multicolumn{11}{|c|}{ All house types (BF): } \\
\hline \begin{tabular}{|l|l|} 
Escalator & \\
\end{tabular} & 62,117 & \multicolumn{2}{|c|}{117,761} & 133,116 & \multicolumn{2}{|c|}{89.6} & \multicolumn{4}{|r|}{114.3} \\
\hline Gentrifier & 72,057 & \multicolumn{2}{|c|}{128,446} & 143,316 & \multicolumn{2}{|c|}{78.3} & \multicolumn{4}{|r|}{98.9} \\
\hline Isolate & 53,333 & \multicolumn{2}{|c|}{104,223} & 118,310 & \multicolumn{2}{|c|}{95.4} & \multicolumn{4}{|r|}{121.8} \\
\hline \begin{tabular}{|l|l} 
Transit & \\
\end{tabular} & 81,388 & \multicolumn{2}{|c|}{143,586} & 157,431 & \multicolumn{2}{|c|}{76.4} & \multicolumn{4}{|r|}{93.4} \\
\hline \multicolumn{11}{|l|}{ Flats only (BF): } \\
\hline \begin{tabular}{|l|l|} 
Escalator & \\
\end{tabular} & 62,939 & \multicolumn{2}{|c|}{113,159} & 126,275 & \multicolumn{2}{|c|}{79.8} & \multicolumn{4}{|r|}{100.6} \\
\hline Gentrifier & 73,047 & 120 & & 136,306 & & 4.4 & 13.5 & & & 86.6 \\
\hline Isolate & 56,471 & 102 & & 110,808 & & 1.0 & 8.4 & & & 96.2 \\
\hline Transit & 73,010 & 120 & & 138,964 & & 4.7 & 15.6 & & & 90.3 \\
\hline
\end{tabular}

Source: Land Registry House Price Data, Office for National Statistics Small Area Population Estimates and Economic Deprivation Index

Notes:

1. These figures cover only those local authorities included in this analysis and those sites where detailed site data was reported.

2. BF: areas with brownfield housing development

3. The larger the change in the mean rank, the bigger the improvement made in an area's relative position; and a negative change means an area is getting more deprived in relative terms.

4. **ANOVA test significance level at 0.01 or less and * for significance level at 0.05 or less between areas with and without brownfield housing reuse. 
Table 3 Change in population and EDI by deprived neighbourhood types and by brownfield redevelopment

\begin{tabular}{|c|c|c|c|c|c|c|c|c|c|c|c|c|}
\hline & \multicolumn{3}{|c|}{$\begin{array}{c}\text { Population } \\
\text { change \% } \\
\text { 2001-07 }\end{array}$} & \multicolumn{3}{|c|}{$\begin{array}{l}\text { EDI mean rank } \\
\text { change 2001-05 }\end{array}$} & \multicolumn{3}{|c|}{$\begin{array}{l}\text { Income domain } \\
\text { mean rank change } \\
2001-05\end{array}$} & \multicolumn{3}{|c|}{$\begin{array}{c}\text { Employment domain } \\
\text { mean rank change } \\
2001-05\end{array}$} \\
\hline & All & $\mathrm{BF}$ & $\begin{array}{l}\text { No } \\
\text { BF }\end{array}$ & All & $\mathrm{BF}$ & $\begin{array}{l}\text { No } \\
\text { BF }\end{array}$ & All & $\mathrm{BF}$ & $\begin{array}{l}\text { No } \\
\text { BF }\end{array}$ & All & $\mathrm{BF}$ & $\begin{array}{l}\text { No } \\
\text { BF }\end{array}$ \\
\hline England & 3.3 & $\begin{array}{l}7.0 \\
* *\end{array}$ & $\begin{array}{l}2.5 \\
* *\end{array}$ & 0 & $\begin{array}{c}132 \\
* *\end{array}$ & $\begin{array}{l}-30 \\
* *\end{array}$ & 0 & $\begin{array}{l}97 \\
* *\end{array}$ & $\begin{array}{l}-22 \\
* *\end{array}$ & 0 & $\begin{array}{c}169 \\
* *\end{array}$ & $\begin{array}{l}-38 \\
* *\end{array}$ \\
\hline $\begin{array}{l}20 \% \text { most } \\
\text { deprived IMD04 }\end{array}$ & 2.6 & $\begin{array}{l}7.2 \\
* *\end{array}$ & $\begin{array}{l}1.7 \\
* *\end{array}$ & 147 & $\begin{array}{l}320 \\
* *\end{array}$ & $\begin{array}{c}113 \\
* *\end{array}$ & 215 & $\begin{array}{c}363 \\
* *\end{array}$ & $\begin{array}{l}186 \\
* *\end{array}$ & 69 & $\begin{array}{l}287 \\
* *\end{array}$ & $\begin{array}{l}25 \\
* *\end{array}$ \\
\hline $\begin{array}{l}10 \% \text { most } \\
\text { deprived IMD04 }\end{array}$ & 2.4 & $\begin{array}{l}6.6 \\
* *\end{array}$ & $\begin{array}{l}1.5 \\
* *\end{array}$ & 166 & 176 & 164 & 213 & 192 & 218 & 127 & 182 & 115 \\
\hline Escalator & 1.58 & $\begin{array}{l}5.18 \\
* *\end{array}$ & $\begin{array}{c}0.99 \\
* *\end{array}$ & 91 & 168 & 79 & 169 & 259 & 154 & -1 & 90 & -16 \\
\hline Gentrifier & 3.52 & $\begin{array}{c}8.15 \\
* *\end{array}$ & $\begin{array}{c}2.51 \\
* *\end{array}$ & 197 & $\begin{array}{l}542 \\
* *\end{array}$ & $\begin{array}{c}122 \\
* *\end{array}$ & 185 & $\begin{array}{c}493 \\
*\end{array}$ & $\begin{array}{c}117 \\
*\end{array}$ & 216 & $\begin{array}{c}556 \\
*\end{array}$ & $\begin{array}{c}142 \\
*\end{array}$ \\
\hline Isolate & 0.89 & $\begin{array}{c}3.78 \\
* *\end{array}$ & $\begin{array}{c}0.35 \\
* *\end{array}$ & 207 & 261 & 197 & 227 & 265 & 220 & 192 & 261 & 179 \\
\hline Transit & 4.54 & $\begin{array}{l}10.2 \\
3 * *\end{array}$ & $\begin{array}{c}3.20 \\
* *\end{array}$ & 122 & $\begin{array}{c}390 \\
* *\end{array}$ & $\begin{array}{l}60 \\
* *\end{array}$ & 242 & $\begin{array}{c}458 \\
* *\end{array}$ & $\begin{array}{c}192 \\
* *\end{array}$ & -20.8 & $\begin{array}{c}339 \\
* *\end{array}$ & $\begin{array}{c}-105 \\
* *\end{array}$ \\
\hline
\end{tabular}

Source: Land Registry House Price Data, ONS Small Area Population Estimates and Economic Deprivation Index

Notes:

1. BF: areas with brownfield housing development

2. The larger the change in the mean rank, the bigger the improvement made in an area's relative position; and a negative change means an area is getting more deprived in relative terms.

**ANOVA test significance level at 0.01 or less and * for significance level at 0.05 or less between areas with and without brownfield housing reuse. 
Figure 1 Planned density of residential reuse in most deprived neighbourhoods Source: own calculations based on the National Land Use Database for Previously Developed Land Note: The density figures show the planned density reported in previous NLUD years for sites that have been reused, which are not necessarily the same as the actual density in the redeveloped sites.

$$
130 \times 213 \mathrm{~mm}(300 \times 300 \mathrm{DPI})
$$

